\title{
THE ROLE OF THE STATE IN THE RENEWABLE ENERGY MARKET DEVELOPMENT IN UKRAINE
}

\author{
Olexandra Bulana \\ Institute for Economics and Forecasting, Ukrainian National Academy of Science, Kyiv, Ukraine
}

(C) MESTE NGO

JEL code: 013, P28, Q4, Q42, Q43

\begin{abstract}
:
Renewable energy development is one of the possible solutions to avoid dangerous climate changes and energy dependence. That is why many countries introduce a variety of incentives to attract investments in this sector. The aim of this article is to analyze impact of the Ukrainian state policy on the national renewable energy market. We questioned whether Ukrainians governmental interventions into this market have been successful. We also outline the influence of such incentives on the volume of investments, renewable energy capacity building, as well as on the competition at the market. The research has shown that Ukrainian government has implemented a number of tax and tariff incentives, which gave an impulse for rapid development of the sector. On the other hand, the rules for obtaining subsidies currently contain some risks for competition in the renewable energy sector. We came to the conclusion that despite some significant technical and administrative barriers, governmental incentives for renewable energy represent a rare case of successful subsidies in Ukraine.
\end{abstract}

Keywords: renewable energy market, feed-in tariff, tax incentives, local content requirement

\section{INTRODUCTION}

Renewable energy is developing fast in many countries in the world. This energy uses inexhaustible resources available at any country in the world. Meanwhile, almost no hazardous emissions to atmosphere arise from renewable energy producing facilities. Moreover, renewable energy could be characterized as energy of the future, as it is deeply linked to development of innovative technologies. That is why many governments support renewable energy development with different types of subsidies, to

The address of the author:

Olexandra Bulana

莑" alexandra_bulanaja@yahoo.com achieve ambitious goals of gradual replacement of energy produced from traditional sources with energy produced from renewable sources.

Meanwhile, Ukrainian industry is still based on outdated technologies, what has made the national economy one of the most energy inefficient in the world. In Ukraine, the major part of electricity is produced at cogeneration plants which are primary using coal. This is one of the most environmentally unfriendly ways of electricity production. Moreover, currently Ukraine imports more than $50 \%$ of all energy resources required for satisfying its needs. Thus, renewable energy development is one of the possible solutions to deal with energy dependence and ecological issues. However, Ukraine's energy production from renewable sources currently is far below its potential. 
Succesfull good practice of different countries shows sugnifficant role of the state in the development of renewable energy sector. Twenty of 27 EU countries already use feed-in tariff as renewable energy support instrument. And in these countries the majority of newly installed wind onshore and photovoltaics capacity in Europe has come into operation (Ragwitz M., Winkler J., Klessmann C., Gephart M., Resch G., 2012).

This article represents an attempt for theoretical and empirical analysis of the governmental role in the renewable energy market development in Ukraine. It's intended to give an overwiew of state policy in this sector. The aim of the paper is to define whether governmental interventions were significant and sufficient for the sector development.

\section{MARKET FAILURES OR THE REASONS, WHY GOVERNMENT SHOULD INTERVENE INTO RENEWABLE ENERGY MARKET}

Economic theory provides different motivations for renewable energy stimulating policy. Gillingham K. and Sweeney J. describe 12 types of market failures existing at renewable energy market (Gillingham K., Sweeney J., 2010). Market failure is a situation where optimal choices deviate from economically efficient choices. Government interventions can eliminate existing market failures and in such way improve net social welfare.

Below we outline the most common market failures for Ukrainian renewable energy market.

Environmental externalities are the main motivation to support renewable energy. Traditional energy emits a variety of pollutants. These pollutants have a strong negative impact on the economy. They are harmful to the environment and public health. Due to the environmental contamination, the costs related to medical services, environmental protection and for cleansing the environment would increase for society. These external costs of the traditional energy sources usually are not priced until the government intervenes (for example, in the form of excise duty or environmental tax). If the emissions are not priced, there will be no incentive for businesses to introduce new technologies or processes in order to reduce the emissions or mitigate the external costs resulting thereof. The main advantage of renewable energy is low level of emission. Thus, this type of energy is less costly for society even if the price is higher.

Ecological tax rate in Ukraine is lower than the rates applied in the EU countries (Shkarlet S., Petrakov I., 2013). Ukrainian excise duty for gasoline is one of the lowest in Europe as well. Thus renewable energy stimulation policy is the main tool to eliminate negative environmental externalities. Ukrainian government expects that renewable energy will gradually replace traditional energy sources in energy consumption structure and emissions would decrease.

National security externalities. Oil and gas production is highly concentrated in few countries, such as Middle East, Nigeria, Russia and so on. The main supplier of gas and oil to Ukraine is Russia. Therefore, there are high risks for Ukraine related to import of energy sources. Ukrainian dependency from Russian gas is very dangerous for national security. Series of gas disputes between Ukraine and Russia in 20052009 concerning natural gas supplies, prices, and debts have proved this. Thus, renewable energy promotion is a way to decrease imported natural gas consumption that is extremely important for national security.

Economies of scale, particularly increasing returns to scale, refers to a situation where average cost of producing a unit decreases as the rate of output at any given time increases, resulting from a non-convexity in the production function due to any number of reasons, including fixed costs (Gillingham K., Sweeney J., 2010). Economy of scale is a main reason of so called "feed-in tariff degression", a mechanism according to which the price (or tariff) ratchets down over time. Many countries introducing feedin tariff expect that increase in the volume of renewable energy equipment production and technological progress will decrease renewable energy production costs. But at the initial stage where the volume of production is low, renewable energy sector needs support from the government to reach economy of scale. 
R\&D. Where businesses invest in R\&D, they are usually not able to capture all of the knowledge gained from their investment. For example, successful R\&D by a particular firm (e.g., R\&D that created a new class of solar photovoltaic cells) would likely result in a portion of new knowledge being broadly shared, through trade magazines, reverse engineering by its competitors, or technical knowledge employees bring with them as they change employment among competitive firms (Gillingham K., Sweeney J., 2010). R\&D provides a big gain for society as it has significant effect of technological progress, human capital development and economical growth. Thus the gain for society from particular $R \& D$ is sometimes bigger than for the firm that has actually carried it out. Empirical work suggests that additional $R \& D$ investment in renewable energy will at least partly displace R\&D in other sectors (Gillingham K., Sweeney J., 2010). That is why the state is interested in stimulation of R\&D investments. However, as the level of $R \& D$ subsidies in Ukraine are very low (not only for renewable energy sector, but for other sectors too) this argument is rather theoretical.

\section{DEMAND AND SUPPLY FOR}

\section{RENEWABLE ENERGY IN UKRAINE}

Ukrainian economy still remains one of the most energy-consuming in the European region. According to the International Energy Association, the ratio of energy consumption to GDP is ten times more than the average ratio in OECD countries. Thus, there is a strong demand for energy while the energy consumption is very high (IEA, 2012). The main sources of energy production in Ukraine are as follows: natural gas $40 \%$, coal $-31 \%$ and nuclear power $-17 \%$. Meanwhile, the share of renewable energy in 2011 was only $0,5 \%$. Despite the strong demand for energy from the industry producers, they actually consume energy mainly from other sources (substitute goods) such as oil and gas.

There are many constraints in the supply development of renewable energy in Ukraine:

- The production costs of renewable energy are higher than from traditional sources;

- There are a lot of technical issues for building renewable energy capacities on Ukraine: difficulties with connection of generating facilities to the general electricity grid; burdensome procedures for obtaining various type of permits and renting the land for building renewable energy facilities etc;

- High level of interest rates for bank loans.

Nevertheless, Ukraine holds a significant potential for renewable energy development, especially nature potential. Ernst \& Young estimates that Ukraine has $2.3 \mathrm{GW}$ of small-scale hydroelectric potential, compared to its current installed capacity of $150 \mathrm{MWh}$. Wind power potential is estimated to be 19-24 GW with only $87 \mathrm{MW}$ installed at the end of 2009. Ukraine also has strong solar energy potential, with irradiation of around $800-1450 \mathrm{kWh} / \mathrm{m}^{2}$ per year, but the current installed capacity was negligible at the end of 2010 (Ernst\&Young, 2013). Furthermore, Ukraine's renewable energy sector currently produces power at a much lower cost than in the other countries. For instance, producing of 1 MWh of wind energy in Ukraine costs approximately 33 USD, compared with 145 USD in Czech Republic and 50 USD in China (OECD, 2012).

Thus Ukrainian supply and demand model of renewable energy sector without government intervention looked like in such way, that the quantity of energy proposed from suppliers was not enough to meet the market potential. The sector stagnated and had almost no development. The main reason for this was considerable market barriers envisaged above and other specifics of doing business in Ukraine (e.g., high level of corruption).

\section{GOVERNMENT INTERVENTIONS}

\subsection{Feed-in tariff}

In 2008 in Ukraine has introduced a price floor for the energy from renewable sources (implemented by means of feed-in-tariff). According to Ukrainian legislation, the Wholesale electricity market (being a fully state-owned company) has to purchase all the energy produced from renewable sources for the price equal the level of feed-in-tariff. This price floor did not result in decrease of quantity demanded on the market as the Wholesale electricity market, energy-distributing companies and consumers 
are anyway obliged to buy this energy at the level of feed-in-tariff, even if this price is not economically substantiated.

Naturally, green electricity turns out to be more expensive, so there is no economic point for final consumers in purchasing it. Yet, there is no mechanism for cost-cutting in order to make green electricity cheaper for end-use consumers. Thus, the only actual buyer of green electricity is the Wholesale electricity market (Trypolska, 2012). Actually the main influence of feed-in tariff on the market is increasing costs of Wholesale electricity market for purchasing such electricity from producers.

The level of feed-in tariff in Ukraine is high enough to compensate the the production costs to the energy generating facilities. According to Trypolska research, the average costs of electricity production from biomass is 0,057 euro/kWh, but the current level of ffed-in-tariff is 0,127 euro/kWh for solar energy average cost are 0,112 euro/kWh and feed-in tariff level 0,143 euro/kWh, for wind energy average costs are 0,027 euro/kWh and feed-in tariff 0,066 euro/kWh (Trypolska, 2012).

Table 1. The level of procurement prices for electricity produced from different types of energy sources on November 2013 (Wholesale electricity market of Ukraine, 2013)

\begin{tabular}{|l|l|l|}
\hline $\begin{array}{c}\text { Type of } \\
\text { energy } \\
\text { source }\end{array}$ & $\begin{array}{c}\text { Procurement } \\
\text { price } \\
\text { hryvna/kWh, }\end{array}$ & $\begin{array}{c}\text { Price } \\
\text { equivalent in } \\
\text { euro* } \\
\text { (euro/kWh) }\end{array}$ \\
\hline $\begin{array}{l}\text { Nuclear } \\
\text { energy }\end{array}$ & 0,22 & 0,02 \\
\hline $\begin{array}{l}\text { heat power } \\
\text { plant }\end{array}$ & 0,58 & 0,05 \\
\hline Hydro & 0,22 & 0,02 \\
\hline Small hydro & 1,28 & 0,12 \\
\hline Wind power & 1,25 & 0,12 \\
\hline $\begin{array}{l}\text { Solar } \\
\text { energy }\end{array}$ & 5,05 & 0,47 \\
\hline
\end{tabular}

${ }^{*}$ At the exchange rate for 19th November 2013

As for November 2013, the level of feed-in tariff for solar energy was about 50 euro cents/kWh (the actual level of tariff is established in hryvna, hence the price in euro depends on the exchange rate), what is the highest in Europe and more than twice as in Germany in 2012 (Zhang, 2013). The main source of compensation for such high level of feed-in tariff is the low level of prices for energy produces from the other energy sources. Table 1 shows procurement prices of Ukrainian Wholesale electricity market for electricity produced from different types of energy sources. National Electricity Regulatory Commission of Ukraine (a governmental authority) establishes all the tariffs for electricity produced from all the types of the energy sources in Ukraine. The energy produced from nuclear and hydro energy is "the cheapest". As there is no competitive energy market in Ukraine, high difference in regulated tariffs results in a situation where nuclear and hydro energy producers actually subsidize the high level of feed-in tariffs in Ukraine.

On the other hand, high level of feed-in tariff in Ukraine is justified by a number of economic and administrative barriers.

- The regulatory environment is unstable in Ukraine. Any new legislative rules concerning doing business may change in every moment (for instance concerning local content requirement, which will be discussed below).

- General conditions for doing business are poor because of high level of corruption and complicated system of tax administration.

- Uncertainties concerning Ukrainian public finance sustainability and weak banking sector make it difficult to obtain financing for building of renewable energy capacities.

- There are some technical issues concerning limited technical capabilities of electricity grid.

All of these factors make investments in Ukranian renewable energy sector risky. And therefore high level of feed-in tariff compensates high risks of investments.

\subsection{Tax incentives}

Almost simultaneously with feed-in tariff, different types of tax incentives have been introduced to support renewable energy production. These incentives include various combinations of exemption from corporate income tax, VAT, customs duty and land tax.

Corporate income tax exemption applicable to production of renewable energy inter alia includes:

- Until 1 January 2021, any profits arising from the main activity of an electricity generating 
company which generates electricity only from renewable energy sources (hereinafter $\mathrm{RES}$ ) is exempt from corporate income tax (CIT);

- $\quad 80 \%$ of the profit derived from transactions involving RES producing equipment and components, is exempt from CIT. To qualify for an exemption, the funds in question should be used by the company to increase its production;

- VAT/Customs Duties Exemption

- Importation into Ukraine of the raw materials, equipment and components used in the production of electricity from RES (analogs of which are not produced locally) is exempt from Ukrainian customs duty and import VAT.

- Temporarily until 1 January 2019, supply of RES equipment and facilities within the territory of Ukraine are exampt from VAT.

\section{Land Taxes}

RES producers pay only $25 \%$ of the normal payable amount of land tax.

Thus, the government interventions in the form of feed-in tariff and tax incentives have a strong impact on the renewable energy market. By introduction of feed-in tariff, the suppliers are able to ensure that all the energy produced will be demanded on the market at the distinct price. Tax incentives decrease production costs and make the production of renewable energy cheaper. Consequently, the level of the renewable energy produced in Ukraine increases and the investments in the sectors are growing.

The level of tax exemptions for renewable energy is really large as for tax relives just for one sector. In 2010 it was $0,15 \%$ of GDP, in $2011-0,27 \%$ of GDP and in $2012-0,18 \%$ of GDP. The most part of thee tax exemption was given for VAT exemption (fig. 1).

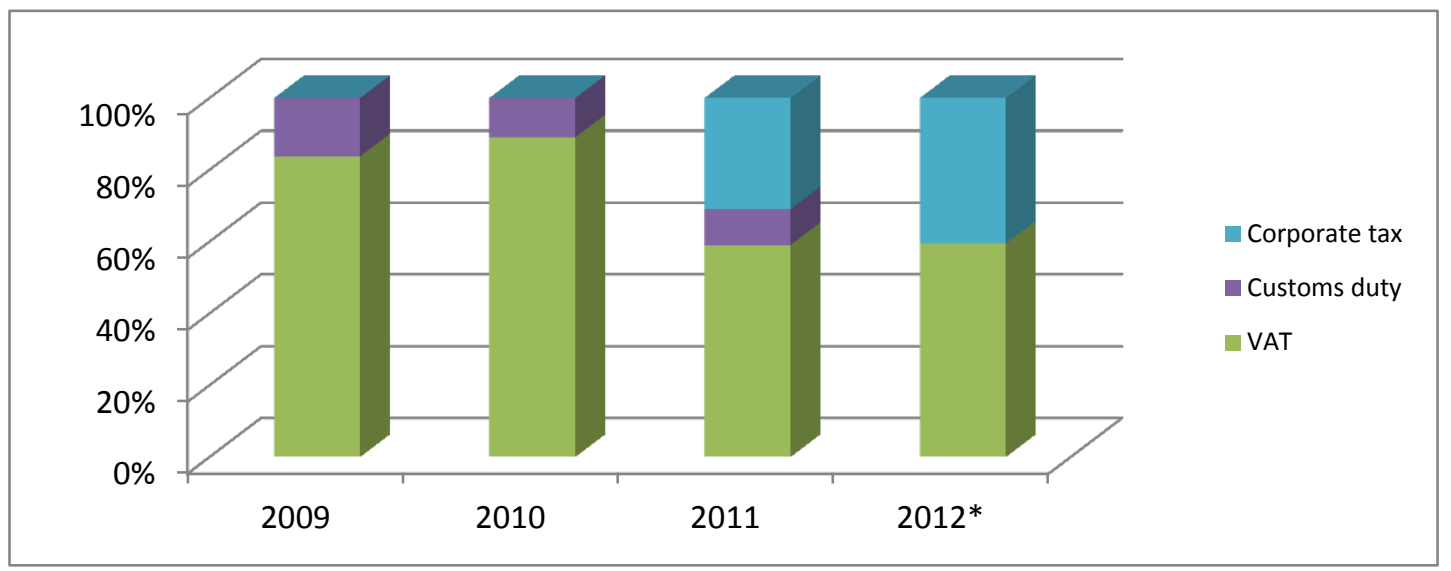

${ }^{*}$ customs duty tax exemption data in 2012 is not available

Fig. 1 The structure of renewable energy tax exemptions in Ukrain (Ministry of Revenue and Duties of Ukraine)

Tax exemption from VAT for renewable energe equipment produced in Ukraine amounted of 39 million hrivnas in 2011. Tax exemption from VAT for importation of equipment was more than 2 billion hrivnas. Thus, foreign producers of equipment benefit from tax exemptions more than Ukrainian producers. Ministry of Revenue and Duties of Ukraine reported about wide use of tax exemptions for importation in different schemes for tax evasion. Nontransparent procedure for obtaining the tax exemption allows unfair firms to pay fewer taxes.
Anyway, the introduction of feed-in tariff and tax exeption has had a sustainable effect on the market, increasing the quantity of supplied energy. State Agency on Energy Efficiency and Energy Saving of Ukraine reported about the total power produced from renewable sources this year reached $600 \mathrm{MWh}$. At the moment 120 renewable energy plants were put into operation in Ukraine. Still, this is not enough to realise the potential of the market. In 2011, the share of renewable energy in energy consumption was less than $1 \%$. Meanwhile in EU this indice has reached $13 \%$. Nevertheless, the level of 


\section{Bulana, O. Renewable Energy Market Development in Ukraine}

MEST Journal Vol.2 No.1 pp.133-140

investments into the sector is much more optimistic. According to Frankfurt School-UNEP Centre, asset finance of renewable energy in Ukraine gained 2,8 \$BN in 2012, what is 205\% more than in 2011. Ukraine shows one of the highest growths of assets investments into renewable energy in the world in 2012 (Frankfurt School-UNEP Centre/BNEF, 2013). Such growth has been caused by financing of a series of hydro projects with the total capacity of $980 \mathrm{MW}$ and worth $\$ 2.1$ billion on the Dnister River.

\section{IMPACT OF THE GOVERNMENTAL POLICY ON THE COMPETITION IN THE SECTOR}

As mentioned above, governmental policy was a strong stimulus for development of the renewable energy sector in Ukraine. Nowadays, such type of business still cannot survive without governmental aid (i.e. costs and risks are too high). Thus, the main restriction for competition in this sector is eligibility for feed-in tariff and tax incentives.
In November 2012 Ukrainian Parliament has significantly changed the requirements to qualify for feed-in tariff. The main change was the introduction of local (Ukrainian) content requirement of ratio of works, materials and services, which must be met when establishing a new energy generation facility. According to the law, starting January 1, 2012 the share of raw materials, plant and equipment, works and services of Ukrainian origin in the construction cost of the renewable energy generation facility has to be at least $15 \%$ - starting from January 1 , $30 \%$ - starting from January 1, 2013, and 50\% starting from January 1, 2014.

"Local content" may become an issue for further sector development, as there are just a few renewable energy equipment manufacturers in Ukraine (European - Ukrainian Energy Agency, 2011). The other issue is whether the quality of locally manufactured components would be comparable with quality of the analogical imported goods (European - Ukrainian Energy Agency, 2011).

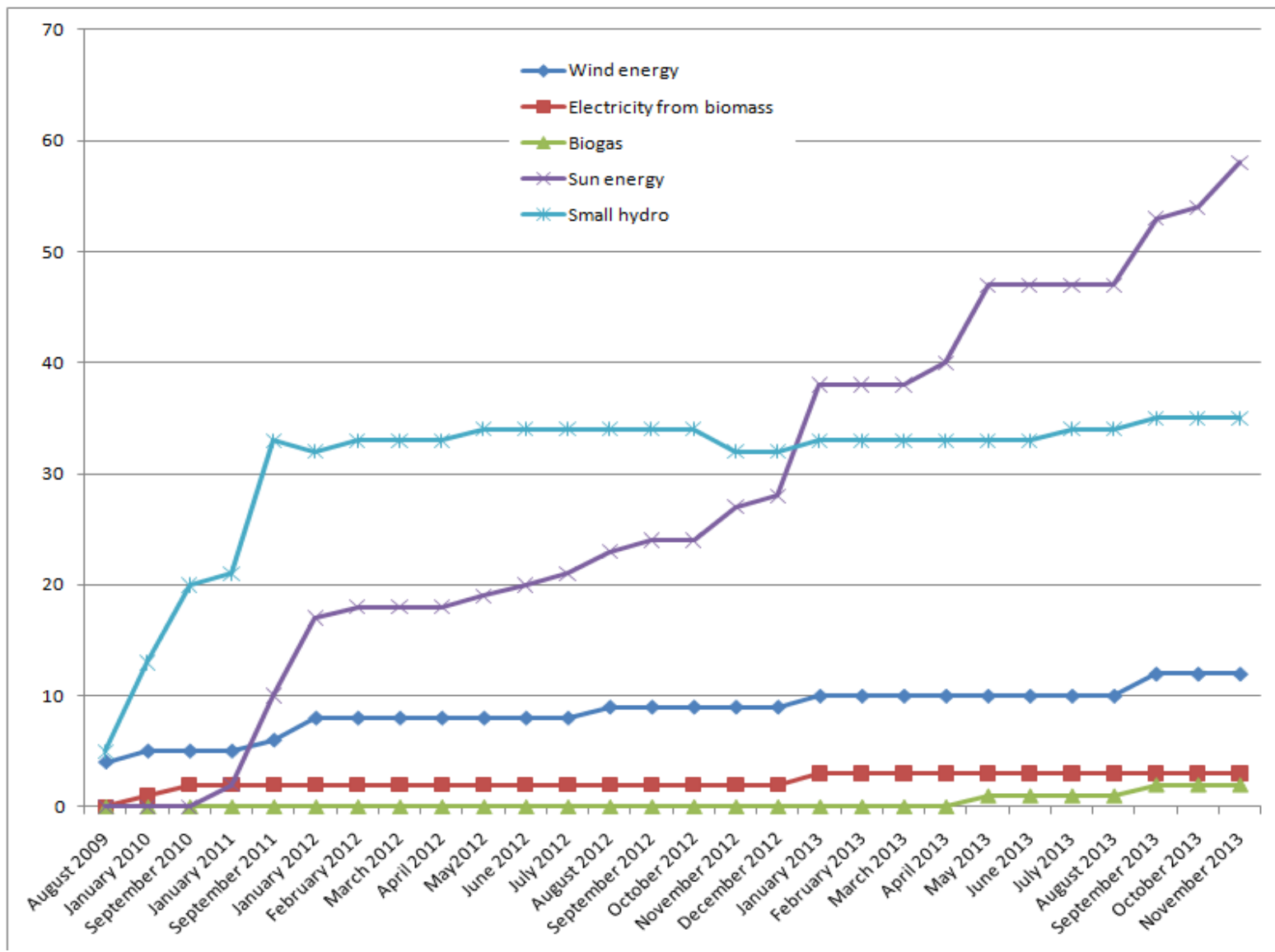

Fig. 2. Number of electricity producers who have obtained a feed-in tariff permit (National Electricity Regulatory Commission of Ukraine) 
Prior to the introduction of local content requirement, the number of entities allowed to use a feed-in tariff was growing very quickly. But as it may be seen from the fig.2, after November 2012 the tendencies in qualification for feed-in tariff remain almost unchanged. This could be explained by obtaining of the tariff by the entities that put into operation their generation facilities before the local content introduction, but for some reason did not get the tariff for that moment. Anyway, there is too little time to estimate the real effect of the local content requirement on the renewable energy market in Ukraine.

Another restriction for renewable energy market competition is comprehensive availability of tax incentives provided by state. As for 2012 only 59 entities used CIT Exemption, but more than 70 have put their production facilities into operation at that moment. As it has been mentioned before, the procedure for obtaining the feed-in tariff and tax incentives is complicated. Thus, for example in order to qualify for exemption from customs duty and import VAT, the equipment has to obtain a positive conclusion from the Ministry of Economic Development and Trade of Ukraine, and afterwards get registered with the Cabinet of Ministers of Ukraine (i.e. each item of the exempt goods has to be included in the special list approved by the Government) (Trypolska, 2012). Given the general level of corruption in Ukraine (according to Transparency International Corruption Indices Ukraine have got 144th rank from 176) there are some concerns whether this procedure could be easier and faster for some entities, than for other.

Before the "local content requirement" introduction the market could be characterised as monopolistic competition, as the market entrance required some access to financial recourses, specific technologies and knowledge, which can be regarded as entrance barriers. There are some concerns that local content requirement can transform this market in oligopolistic, due to the limited supply of Ukrainian renewable energy equipment and limited access to them. For example, PJSC "Semiconductor Plant", the biggest Ukrainian producer of polysilicone (supplier materials for sun energy plants) is wholly owned by ACTIV SOLAR, the biggest developer of large-scale photovoltaic installations in Ukraine (producer of sun energy and thus polysilicone consumer). Thus, such group companies will certainly have an advantage on the Ukrainian renewable energy market.

It is possible to conclude that certain conditions for obtaining feed-in tariff and tax incentives in Ukraine may have restrictive effect on the renewable energy market in Ukraine, however it is too early to test this hypothesis in practice.

\section{CONCLUSIONS}

Renewable energy subsidies represent a rare case of successful subsidies in Ukraine. For the past few years, the new innovative and environmentally friendly sector started rapid development in Ukraine. It may be opined that the benefits for the whole society resulting from renewable energy development will exceed just simple economic profit of a limited number of businesses.

This research has shown renewable energy industry made a success due to the feed-in tariff and a number of tax incentives. As in the middle of 2000-s, the development of the sector was weak, but after 2009 begins the rapid emergence of firms producing renewable energy.

Notwithstanding with the above, the rules for obtaining subsidies still contain some major risks for sector development. First of all, due to the difficult procedure for obtaining tax exemption, some entities cannot take advantage of these benefits. Moreover, the local content requirement limits the range of businesses which can enjoy feed-in tariff in Ukraine. These restrictive rules may limit the competition in the sector. In the moment the price for renewable energy is regulated by the government. In few years after achieving the point where the economy of scale starts to work, the sector will be competitive without any subsidies. Thus, it is very important to maintain maximum possible competition in the sector so that consumers can get the most favorable price. 


\section{WORKS CITED}

Ernst\&Young. (2013). Renewable energy country attractiveness indices. Retrieved from http://www.ey.com/UK/en/Industries/Cleantech/Renewable-Energy-Country-AttractivenessIndex.

European - Ukrainian Energy Agency. (2011). Market Overwiew. Ukraine's Solar Energy: Current Status. Retrieved from www.euea-energyagency.org.

Frankfurt School-UNEP Centre/BNEF. (2013). Global Trends in Renewable Energy Investment. Retrieved from http://www.fs-unep-centre.org.

Gillingham K., Sweeney J. (2010). Market Failure and the Structure of Externalities. Retrieved from http://www.yale.edu/gillingham/Market\%20Failure\%20and\%20the\%20Structure\%20of\%20Ext ernalities.pdf.

IEA. (2012). Ukraine 2012, Energy Policies Beyond IEA Countries series. Retrieved from http://www.iea.org/publications/freepublications/publication/UK_Summaryplus.pdf.

National Electricity Regulatory Commission of Ukraine. (n.d.). Retrieved from www.nerc.gov.ua.

OECD. (2012). Attracting Investment in Renewable Energy in Ukraine. Retrieved from http://www.oecd.org/countries/ukraine/UkraineRenewableEnergy.pdf.

Ragwitz M., Winkler J., Klessmann C., Gephart M., Resch G. (2012). Recent developments of feed-in systems in the EU - A research paper for the International Feed-In Cooperation. Retrieved from http://www.feed-in-cooperation.org/wDefault_7/content/research/index.php.

Shkarlet S., Petrakov I. (2013). Environmental Taxation Evolution in Ukraine: Trends, Challenges and Outlook. Retrieved from http://mpra.ub.uni-muenchen.de/45168/1/MPRA_paper_45168.pdf.

Trypolska, G. (2012). Feed-in tariff in Ukraine: The only driver of renewables' industry growth? Energy Policy, 645-653.

Wholesale electricity market of Ukraine. (2013). Retrieved from http://www.er.gov.ua/.

Zhang, F. (2013). How fit are feed-in tariff policies ? evidence from the European wind market. Retrieved from http://documents.worldbank.org/curated/en/2013/02/17390570/fit-feed-in-tariffpolicies-evidence-european-wind-market.

Received for publication:

Revision received:

Accepted for publication:
18.12.2013

27.12.2013

05.01 .2014

\section{How to cite this article?}

Style - APA Sixth Edition:

Bulana, O. (2014, 01 15). The role of the state in the renewable energy market development in Ukraine. (Z. Čekerevac, Ed.) MEST Journal, 2(1), 133-140. doi:10.12709/mest.02.02.01.14

Style - Chicago Fifteenth Edition:

Bulana, Olexandra. "The role of the state in the renewable energy market development in Ukraine." Edited by Zoran Čekerevac. MEST Journal (MESTE) 2, no. 1 (01 2014): 133-140.

Style - GOST Name Sort:

Bulana Olexandra The role of the state in the renewable energy market development in Ukraine [Journal] = Renewable energy market development in Ukraine // MEST Journal / ed. Čekerevac Zoran. - Belgrade : MESTE, 01 15, 2014. - 1 : Vol. 2. - pp. 133-140. - ISSN 2334-7058 (Online); ISSN 2334-7171.

Style - Harvard Anglia:

Bulana, O., 2014. The role of the state in the renewable energy market development in Ukraine. MEST Journal, 15 01, 2(1), pp. 133-140.

Style - ISO 690 Numerical Reference:

The role of the state in the renewable energy market development in Ukraine. Bulana, Olexandra. [ed.] Zoran Čekerevac. 1, Belgrade : MESTE, 01 15, 2014, MEST Journal, Vol. 2, pp. 133-140. ISSN 2334-7058 (Online); ISSN 2334-7171. 